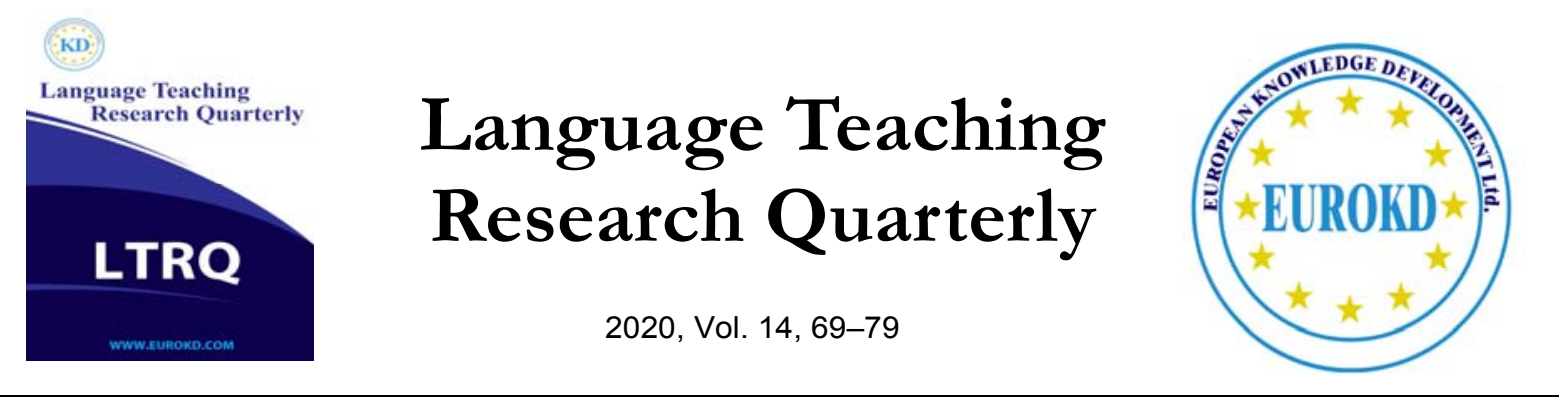

\title{
Terminological Field «Tourism» in English Tourism Discourse
}

\author{
Viktoriia Prima \\ Kyiv National University of Trade and Economics, Ukraine
}

Received 22 June 2019 Accepted 10 November 2019

\begin{abstract}
The article outlines main aspects of study of the English tourism terminology, in particular, functional. General specific features of the English guides and peculiarities of tourism terms functioning in them have been viewed in the article. The aim of our work is to consider the functioning of the English tourism terminology in guidebooks to Ukraine. The research is based on the materials of these English-speaking guides on line: World Travel Guide and Travel to Ukraine (the Official Travel Website and Guide to Ukraine). In linguistics a guidebook is considered a kind of tourist discourse genre. Characteristic features of tourist guides are a high degree of generalization, precision, information and impersonality. The main functions of guides are informative (presenting factual information) and advertising (creating a positive image of a specific tourist site that aims to interest potential tourist on his visit). These features influence the choice of vocabulary of travel guides. Several micro fields are presented in the English tourism terminology. They are organization of tourism, accommodation, transport, food, leisure time. Implementing promotional and informational functions also contributes to polycodenature of the guide - the presence of illustrations, on the one hand, renders factual information (various maps) on the other - helps to create a high positive image of a particular object (photo).
\end{abstract}

Keywords: Discourse, Terminological Field, Term, Terminology, Guide Book.

\section{Introduction}

One of the main tasks of modern linguistics is a stratification of the vocabulary of certain language by different criteria, mainly, by the sphere of usage of particular lexical unit. The great importance achieves learning of sublanguages, which serve in different spheres of human professional activity. Nowadays there exist numerous available researches general theoretical questions of terminology (Ahmanova, 2007), as well as separate terminological systems. At the same time terminological systems of relatively new branches of human activity, among which is 
a tourist terminological system starting to develop and formulate as an industry only at the beginning of XX century, are still remain insufficient investigated (Agafonova 2002).

Among recentiy published works we should pay attention to the Elena Manca (Innovative Perspectives on Tourism Discourse (2018), 91-110), whose study has relevant implications for cross-cultural tourist communication: the identification of the features which are more commonly and more frequently used by a culture can be a starting point towards the development of a model for the creation of successful tourist products. The presence of key techniques contribute to a more positive disposition on the part of consumers towards the products advertised, and to reach the final aim of tourist products, that is to say convincing readers to become actual tourists.

The topicality of the work is determined by the choice of English tourist guidebooks to Ukraine as it practical material. That gives an opportunity to study not only functional, but also socio-cultural peculiarities of analyzed terminological unites, which show the attitude of English society to Ukraine, its material and cultural realities through the lens of tourist services.

The analysis of the theoretical and practical aspects of terminology in the works of contemporary domestic linguists showed that the most common trend is the union of two aspects - namely functional and systematic - for complete coverage of the characteristics of a certain terminology. Among the main tasks to be solved in these studies, we note in particular the development of complex model analysis of terms for use in lexicographical practice; structural and semantic features of word terms; analysis of relationships within the terminology system; systematization of terms into certain groups according to semantic features; establishing ways of motivation and origin of terminological vocabulary and its periodization; exploring the functional characteristics of these units; identify meaningful connection and functional settings of terms.

A travel guide (a guide book) is defined as a printed book, audiovisual or electronic directory, which is dedicated to a particular country or city, contains information on the geographical, historical and cultural features of the country, its attractions, and available types of accommodation, food, transport and entertainment and is usually accompanied by illustrations, diagrams, maps.

In linguistics a guide book is considered as a genre of tourism discourse. The characteristic features of tourist guides are a high degree of generalization, accuracy, informativeness and impersonality. The main functions of guides are informative (presenting factual information) and advertising (creation of a positive image of a specific tourist site that aims to interest a potential tourist on his visit). These features determine the vocabulary of travel guides.

\section{Questions as Partitions}

The main aimof our research work is to consider the peculiarities of functioning of terminological field «tourism» in English tourist guidebooks to Ukraine. The material is the selection from the following English tourist guidebooks:World Travel Guide, Travel to Ukraine (the Official Travel Website and Guide to Ukraine). 
In theoretical terms, Critical Discourse Analysis will help us see how social structures operate, through the mediation of social practices, on the people involved in social events (in the present case, the "agents" responsible for the publication of the Lonely Planet text and its translation). The theoretical framework used in this study includes a review of the 1999 work of (Fairclough, 2003), Fairclough's 2001 and 2003 publications, and (Durán Muñoz, 2011). The term discourse is used here in a general sense for verbal language (and images), but also as an element of social life dialectically related to other non-discoursal elements (Fairclough, 2003). Discourses are different ways of representing aspects of the world from different perspectives, since "differently positioned social actors 'see' and represent social life in different ways, different discourses" (Fairclough, 2003, p. 123). A closer look at the texts through a corpusbased study will help us understand the way the discourse of tourism operates in translation. In order to facilitate a comparison between source and target texts, we will use the COPA-TRAD parallel corpus computer tool (Fernandes, 2004). Some of the multimodal aspects of the selected texts, such as web layout and images, will be studied under the light of (Kress (2004)). In the following sections we will present a brief notion of tourism today, the network of practices, people and institutions behind the Lonely Planet texts, company-consumer interaction in English and Portuguese, a textual analysis (linguistic peculiarities of this discourse) and a description of the visual composition of the texts in their respective websites.

\section{Main Approaches And Principles}

According to the analysis of theoretical and practical aspects of the study of terminology in the works of modern domestic linguists, the most common tendency is to combine two aspects, namely functional and systemic, to fully cover the features of a particular terminological system. Among the main tasks that are solved in these studies, we will note, in particular, the development of a comprehensive model for the analysis of terms for use in lexicographic practice; study of structural, semantic and word-forming features of terms; analysis of systemic relationships within the term system;systematization of separate groups of terms by semantic feature; establishment of ways of origin, motivation and periodization of terminological vocabulary; study of the functional characteristics of these units; identifying a link between meaningful and functional terms characterization of determinological processes within the system; development of thesaurus of terminology of a certain sphere of human activity.

According to the principles of "field" approachto the modeling of lingual subsystemswe should consider all the corpse of English tourist terminology as terminologicalfield (Ahmanova 2007), which has constant structure and is based on some kinds ofrelations between their components. We conducted thematic analysisof English tourism terminology and separated in its structure five microfields, which describe відображають наявні existed sub branches in tourism sphere, namely: «organization of tourism», «organization of habitation», «organization of transporting», «organization of nutrition», «organization of leasure», each of them contains several lexico-semantical groups (ctd. - LSG). 
We determine the travelguide as a printed book, electronic or audiovisual guide for a specific country or city, and include information about the country's geography, history, culture, its attractions, types of habitat, food, transport and entertainment, and is usually accompanied by illustrations, diagrams and maps (Kiseljova 2008). In linguistics, the guide is regarded as a genre type of tourist discourse (Filatova 2012). The main characteristic features of tourist guides are a high degree of generalization, accuracy, informativeness and impersonality. The main functions of the travelguides are informative (presentation of factual information) and advertising (creating a positive image of a certain tourist object, which aims to interest a potential tourist in its visit). It is these functions that determine the lexical composition of tourist guides.

As the researchers note, the text of the travelguide is more and more gravitating towards such genres of journalistic style as essay and journal article. One of the most striking features of a journalistic style is the usage of their own names, geographical names and toponyms, along with emotional words and phrases with positive connotations, intuitive metaphors and comparisons. Features of the popular science style are also reflected in the text of the guide, because it seeks to provide the reader with more detailed factual information about the sights and maximize its background knowledge (Kiseljova, 2008).

\section{Travelguide Analysis}

Our analysis showed that the structure of the analyzed electronic travelguides is identical. They primarily contain general information about Ukraine, which is placed on the main page of the guidebook. For example:

"Vast and vaguely mysterious, Ukraine is barely known to outsiders despite being one of the largest countries in Europe. It's a country of varied landscapes and surprising cultural diversity"( http://www.traveltoukraine.org).

The authors of the study guides devote great attention to the descriptive cultural features of our country. Thus, in particular, all sources contain information on religious denominations:

"About $60 \%$ of Ukraine's population claim to be either not religious or do not identify with a particular church. Around 15\% are members of the Kyiv Patriarchate of the Ukrainian Orthodox Church while 11\% belong to the Moscow Patriarchate. Another 5\%, mostly in western Ukraine, adhere to the Uniate (Eastern-rite) or Ukrainian Greek Catholic tradition. Other minorities include the Ukrainian Autocephalous Orthodox Church, the Roman Catholic Church and various Protestant groups. There is also a Muslim minority (mainly consisting of Tatars in Crimea), which makes up 12\% of the population" (http://www.worldtravelguide.net/ukraine).

In addition, the drafters of travel guides emphasize practical advice on the behavior of a foreigner in Ukraine, his perception by the natives and the rules of social behavior. This is well illustrated by the following examples:

"Ukrainian people are generally warm and friendly to visitors. It is not at all uncommon for Ukrainians to invite strangers into their own homes. Shoes should be removed on entering a home. Formal attire is rarely required, though people dress smartly for the theatre. Visitors should avoid ostentatious displays of wealth in public places. Men should not shake a woman's 
hand unless it is offered to them. Women should cover their heads when entering a church or mosque" (http://www.traveltoukraine.org).

To the important from the practical point of view of information also include information regarding the climatic features of Ukraine:

"Ukraine has a temperate continental climate with cold, snowy winters and warm summers. Lightweight clothes needed in summer, light-to mediumweight in the spring and autumn and heavyweight in the winter" (http://www.traveltoukraine.org).

As you can see, this block of information ends with practical pieces of advice, as for the necessary things for the travelers in different seasons.

The encyclopedic information about Ukraine includes also information on its geographical location with the indication of the neighboring countries and the most important reservoirs. The same additional information as the indication of public holidays also has a practical orientation thus, tourists are informed about weekends at official institutions and the opportunity to witness the celebration.

"There are a number of national holidays in Ukraine which are celebrated with gusto. Unlike in some other countries, most of these days have been enjoyed for centuries. Christmas, Easter and Whitsunday are non-business religious holidays - something worth remembering if you're planning to do some shopping or attempting to make business arrangements. It is a law in Ukraine that if a particular holiday falls on a Saturday or Sunday, then the following Monday is an official holiday" (http://www.worldtravelguide.net/ukraine).

An obligatory element of the structure of all tourist guides of Ukraine is the availability of specific information about the rules of entry and the term of stay of foreign citizens in our country.

"To enter Ukraine, a valid passport is required by all nationals referred to in the chart above. As a general rule, visitors requiring visas should apply before travelling. The passport must have two blank pages and must be valid for three months after the date of departure from Ukraine" (http://www.worldtravelguide.net/ukraine).

To purely practical references, we can also refer the information on medical care that foreign tourists can count on in the realities of modern Ukraine:

"The health service does, in theory, provide free medical treatment for all citizens and travellers who become ill. However, as in most parts of the former Soviet Union, health care is a serious problem. The UK and Ukraine have a bilateral agreement on emergency medical treatment, so UK travellers should not need to pay an insurance levy on arrival. Travel insurance is strongly recommended however. Travellers are advised to contact their embassy, in the first instance, for advice on where to get medical help" (http://www.traveltoukraine.org).

Further, the traditional structural elements of the guidebooks are the providing of information on the options of residence in Ukraine, which begins with the general description of the hotel fund of the country:

"Not long ago, most hotels in Ukraine were former Soviet institutions where little had changed for decades. These days, many of the older establishments have been either closed or refurbished 
to a decent standard offering a range of rooms of varying quality and price." (http://www.traveltoukraine.org).

An important information function is also performed by indicating the country's travel options. Practical significance of this information block is amplified by references to firms that, for example, offer car rentals:

"Self-drive hire cars are gradually becoming more available, with both local and international car hire operators renting cars in major towns, especially Kyiv. Several international companies, including Europcar (www.europcar.com), Hertz (www.hertz.ua) and Avis (www.avis.com.ua) offer car pick-up at airports. The minimum age for hiring a car is 21 years" (http://www.worldtravelguide.net/ukraine).

The combination of advertising and information function is observed in the next block of information, which gives information about the features of Ukrainian national cuisine and nutrition available in the country:

"Traditional Ukrainian food, such as that in Russia, is mostly of the 'filling and hearty' variety, with a heavy emphasis on dumplings, potatoes and sour cream. Vegetables tend to be seasonal: excellent fresh fruit and vegetables including peppers, cucumbers and tomatoes are available at markets in summer, while the winter months are dominated by bottled fruit and preserved cabbage. Pizza places are ubiquitous and in the larger towns (especially Kiev) visitors have a wide choice of cuisines that includes French, Indian, Italian and Turkish. Asian restaurants can also be found in the larger urban centers". (http://www.traveltoukraine.org)

Note that the common feature of all the studied guides is to focus on those objects that express the uniqueness, authenticity of Ukrainian culture: cities (Discover gorgeous Lviv, an open-air museum of extraordinary architectural wealth), constructions (Kiev-Pechersk Lavra (the Caves Monastery) is a fascinating living piece of history dating back to 1051), sightseeing (Privoz market - a mustvisit for marketlovers; what ever you buy - always bargain, you'll upset the miff you don't), artefacts (Popular souvenirs include handpainted eggs (pysanky), carved wooden items and hand-embroidered clothes). It is also accentuated that Ukraine as a whole remains unknown for European and American tourists: Big, diverse and largely undiscovered, Ukraine is one of Europe's last genuine frontiers.

The analysis of the corpus of tourism terms showed that they can be classified into several microfields. They are: microfield "tourism organization", microfield "lodging", microfield "transport", microfield "catering" and microfield "leisure."

Microfield "tourism organization" covers the basic concepts of tourism and has five subgroups: 1) "participants of tourism" (tourist, host, tour operator, guide, animator); 2) "forms of tourism" (gastronomic tourism, last-minute tour, all-expense tour); 3) "organizational procedures" (booking, tour cancellation, meet and greet); 4) "tourist documentation" (visa, voucher, traveler's cheque, accident insurance); 5) "advertising of tourist services" (travel catalogue, travel fair).

Microfield "lodging" also contains five subgroups and combines terms that apply to specific nuances of tourist accommodation: 1) "type of hotel" (flotel, boutique hotel, hostel); 2) "room 
types" (single room, suite, family suite); 3) "hotel procedures" (check in, early arrival, late check-out); 4) "hotel services" (room service, wake up call, transfer); 5) "type of accommodation" (bed and breakfast, half board, American plan, European plan).

Microfield "transport" is divided into subgroups depending on the applicable type of transport: 1) "air transportation" (domestic flight, baggage claim, charter); 2) "ground transportation" (car rental, parking lot, buffet car); 3) "water transport" (cruise liner, outside cabin).

Microfield "catering" contains two subgroups: 1) "types of catering" (singles bar, drive-in restaurant); 2) "type of food" (American breakfast, English breakfast, brunch).

Microfield "leisure" - covers lexical items related to the types of rest: 1) "active rest" (diving, bungee-jumping, water skiing); 2) «passive leisure» (animation, variety show, spa) (Prima,2015).

The conducted analysis of the functioning of tourist terminology in these guidebooks showed that in them to one degree or another represented all microfield of the structure of the terminology system "tourism". The informative function of the tourist guide and the briefness of the presentation of information predetermine the presence and level of representativeness of certain LSGs in these microfields. Thus, widely enough representedmicrofield «tourism organization»: LSG «tourism participants» (frequently used terminological units: tourist, touroperator, travel agency); «kinds of tourism» (religious tourism, farm-stay tourism). The most represented group is LSG «tourism documentation» (passport, visa, immigration card, residency permit, health insurance, international driving permit), which is explained by focusing the attention of tourist guides on the rules of entry and stay of foreign tourists on the territory of the country.Atthesametime, theLSG «organizational procedures» isnotrepresentedinthese guidebooks, asitrepresentsmore specific and detailed information, which the tourist encounters in the process of interaction with the travel agency, etc. Characteristic guidebooks' features of briefings and generalization are also determined by the peculiarities of the functioning of the micro-field "organization of residence", which is represented in the sample by only one LSG «types of hotels» (hotel, hostel, five-starhotel, homestay, camping, selfcatering), at the same time other LSG («types of rooms», «hotelservices» and other.) are not relevantfor turist because of their activity. A lot of attention is paid by the planners of travel guides to how you can reach Ukraine and ways of moving within the country. That is why the micropole "organization of transportation" and its structural divisions are quite widely represented in our sample: LSG «air transporting» (airport, airline), LSG «land transportation» (taxi, car rental, minibus, and railway), LSG «water transportation» (cruise, seaport, river port) (Prima,2015).

Microfield «organization of nutrition» is also represented, while it reflects national specificity, which must be interesting for potential tourist. The great role in this sphere is played by the non-equivalent vocabulary, which represents Ukrainian realities, for example, varenyky, borshch, holubsi, deruny, chicken Kiev. Such combination of informational and advertising function one can observe in the peculiarities of functioning of the microfield «organization of leisure» as well, which reflects not only the available recreational opportunities in Ukraine, but 
also tries to attract the travellers: LSG «active rest» (hiking, cycling, skiing, riverrafting, bowling), LSG «passive rest» (livemusic, show, theatreseason).

The material collected during the research shows that in the realization of the advertising function of the tourist guide a large pragmatic load contains qualitative adjectives, the emotional and expressive colour of which contributes to praising the chosen object. Among the recorded adjectives, the most commonly used are the following lexical units: beautiful, fascinating, stunning, striking, unique, engrossing, magnificent, spectacular, exciting, which are reflected in the descriptions of historical and cultural sights of Ukraine. At the same time, the informative function and the desire for the accuracy of factual information lead to the functioning of adjectives with a negative assessment in descriptions of some aspects of the country's infrastructure: "badly litroads, poor condition". Implementation of advertising and information functions is also facilitated by the polycodious nature of the guidebook - the presence of illustrative material, which, on the one hand, visualizes relevant information (different types of map), on the other - helps to form a high positive evaluation of a particular object (photo).

It should be noted that the structure of the analyzed electronic guides is identical. They primarily contain general information about Ukraine, which is placed on the main page of the guidebook. Example:

"Vast and vaguely mysterious, Ukraine is barely known to outsiders despite being one of the largest countries in Europe. It's a country of varied landscapes and surprising cultural diversity. Ukraine's capital, Kiev, founded in the eighth century, displays a heady mix of architecture befitting of a city that was once capital of Kievan Rus, the precursor of the modern Russian state. A wealth of baroque and Renaissance architecture can also be found in Lviv, one of Europe's oldest cities, while Odessa is probably best known for the Potemkin Stairway that featured in Sergei Eisenstein's epic film The Battleship Potemkin" (http://www.traveltoukraine.org).

As we can see from this example, in this block of information, the planners of the guide try to provide as many facts and descriptions of places that might be of interest to a potential tourist. All sources of research contain brief information about the history of the country, with special attention to the present state of affairs. The authors of the study guides devote great attention to the descriptive cultural features of our country. In addition, the authors of the guides emphasize practical advice on the behavior of a foreigner in Ukraine, his perception by the natives and on the norms of social behavior. This is well illustrated by the following example:

"Social conventions: Ukrainian people are generally warm and friendly to visitors. It is not at all uncommon for Ukrainians to invite strangers into their own homes. Shoes should be removed on entering a home. Formal attire is rarely required, though people dress smartly for the theatre. Visitors should avoid ostentatious displays of wealth in public places. Men should not shake a woman's hand unless it is offered to them. Women should cover their heads when entering a church or mosque" (http://www.worldtravelguide.net/ukraine).

As for the functioning of terminological vocabulary in the used guidebooks, the volume of investigated material is about 200 terms used in data sources over 1,000 times. 
The analysis showed that the guidebooks under consideration quite extensively represent microfield "tourism organization". Among the registered elements of "participants of tourism" the most frequently used ones are tourist, tour operator, travel agency, for example:

"The following tour operators offer interesting travel packages and holiday advice on Ukraine". (www.worldtravelguide.net/ukraine).

The next group - "forms of tourism" is presented by several terminological units, in particular, religious tourism, farm stay tourism, for example:

"The site covers all types of tourism - from the extreme outdoor activities to the recreational trips and excursions." (www.worldtravelguide.net/ukraine).

The most represented subgroup in the analyzed guidebooks is "tourism documentation". Among the most frequently used terminological units are the following: passport, visa, immigration card, residency permit, health insurance, international driving permit. This is due to attention of the guide books on the rules of entry and stay of foreign tourists in the country.

"Visa Agencies: Avoid the stress and queues; get a visa agency to arrange your visa. Travel Visa Pro, San Francisco, USA. (866) 378-1722"' (www.worldtravelguide.net/ukraine).

Characteristic features of brevity and generalization also determine the peculiarities of microfield "lodging", represented in the sample only by one subgroup "type of hotel» (hotel, hostel, five-star hotel, home stay, camping, self catering), while other groups ("room types" "hotel services" et al.) are not relevant to tourists because of their detailed character. Thus, the drafters describe accommodation options available in Ukraine. Some of them suggest a general description of housing options, while others - a limited list of names of hotels in various cities and their contact information. Here are some examples.

"Hotels:

Not long ago, most hotels in Ukraine were former Soviet institutions where little had changed for decades. These days, many of the older establishments have been either closed or refurbished to a decent standard offering a range of rooms of varying quality and price. In larger towns and cities, especially in Kiev, Odessa, Lviv and Yalta, there is also a new generation of hotels offering the same high standards found elsewhere in Europe "(www.traveltoukraine.org).

Much attention is paid how to get to Ukraine and ways of moving within the country. Therefore microfield "transport" and its structural subdivisions is widely represented in our sample.

First, we note a large representation of "air transportation" (airport, airline). The researched guides provide information about national and international airlines and flights that carry them:

"Flying to Ukraine

The national carrier is Ukraine International Airlines (PS) (tel: (44) 581 5050; $w w w$.flyuia.com/eng/uk) "(www.traveltoukraine.org).

The most representative group of terminological units is "ground transportation» (taxi, car rental, minibus, railway). Particular attention is drawn to a rather known problem - the state of 
Ukrainian roads. Here we meet with negative adjectives, which however are not subjective and indicate the reality:

"Road: Getting around by road can be difficult outside the main cities: roads are often potholed and driving standards can be poor. Side of road: Right. Road quality: Outside urban areas, Ukrainian roads can be badly lit and in poor condition. Petrol stations and repair garages are becoming more common, but it is recommended to carry spare parts. Diesel, leaded and unleaded petrol are available. Cash is usually required at petrol stations " (www.worldtravelguide.net/ukraine).

Last lexical-semantic group of the given microfield - "water transport" (cruise, sea port, river port) is also presented in our sample. However, the level of representation is rather low, due to the relatively undeveloped system of passenger transportation waterways of Ukraine.

Microfield "catering" is also representative, because it reflects national specificity that might interest a potential tourist. Important role in this is played Ukrainian domestic realities, for example, varenyky, borshch, holubsi, deruny, chicken Kiev. Here are some examples:

"Traditional Ukrainian food, such as that in Russia, is mostly of the 'filling and hearty' variety, with a heavy emphasis on dumplings, potatoes and sour cream.

Specialties:

- Borshch (beetroot soup made with meat broth).

- Varenniki (dumplings containing potatoes, cheese, meat or fruit).

- Deruny (potato pancakes).

- Pelmeny (meat-filled ravioli originally from Siberia).

- Chicken Kiev exists but is better known in the West "(http://www.traveltoukraine.org).

Thus, analysis of the functioning microfield "catering" showed that it is a reflection of a combination of informative and promotional function guide.

This combination of informative and advertising functions is also observed in microfield features "leisure", which reflects not only available opportunities for recreation, but also aims to interest visitors. For example, "active rest" (hiking, cycling, skiing, river rafting, bowling):

"River swimming: Join the locals who swim in summer in the Dnieper River in Kiev and climb onto its ice in winter to fish. Even better, come here for Orthodox Epiphany and be splashed with icy water during the celebrations "(http://www.traveltoukraine.org).

\section{Conclusion}

The level of representation of the studied tourist terminology in English-speaking dictionaries is only a quarter of the 3,000 terminological units (about 700 terms) recorded in specialized encyclopedias.In fact, the whole corpus of tourist terminology, like any other terminology system, is not homogeneous. The division of terminology of a certain sphere into narrow-branch, inter-branch and general scientific has become already traditional.

The material collected during the research shows that in the realization of the advertising function of the tourist guide a large pragmatic load contains qualitative adjectives, the emotional and expressive colour of which contributes to praising the chosen object. Among the recorded 
adjectives, the most commonly used are the following lexical units: beautiful, fascinating, stunning, striking, unique, engrossing, magnificent, spectacular, exciting, which are used in descriptions of historical and cultural monuments of Ukraine. At the same time, the informative function and the desire for the accuracy of factual information determines the functioning of adjectives with a negative assessment in describing some aspects of the country's infrastructure: "badly litroads, poorcondition". The implementation of advertising and information functions is also facilitated by the polycodious nature of the guide - the presence of illustrative material, which, on the one hand, visualizes the factual information (various kinds of maps), on the other hand - helps to form a high positive evaluation of a particular object (photo).

The prospects for further research are seen in a detailed analysis of linguocultural and functionalstylistic parameters of English-language guides.

\section{References}

Agafonova, L.G. (2002). Turizm, gotel'nijtarestorannijbiznes: cinoutvorennja, konkurencija, derzhavnereguljuvannja. K.: ZnannjaUkraïni.

Ahmanova, O.S. (2007). Slovar' lingvisticheskihterminov. M.: KomKniga.

Durán Muñoz, I. (2011). Tourist translations as a mediation tool: misunderstandings and difficulties. Cadernos de tradução, v. 1, n. 27.

Fairclough, N. (2003). Analysing discourse: Textual analysis for social research. London: Routledge.

Fernandes, L. P. (2004). A Portal into the Unknown: Designing, Building, and Processing a Parallel Corpus. CTIS OccasionalPapers, V. 4, 16-36.

Filatova, N.V. (2012). Zhanrovoe prostranstvo turisticheskogo diskursa. In Vestnik MGGU. (2), 56-63.

Ilha Desterro (2016)The discourse of tourism: an analysis of the online article "Best in Travel 2015: Top 10 cities" in its translation to Brazilian Portuguese/ vol.69 no.1.

Innovative Perspectives on Tourism Discourse (2018). Magdalena Bielenia-Grajewska (University of Gdansk, Poland) and Enriqueta Cortes de los Rios (Almeria University, Spain), 360.

Kiseljova, L. (2008). Putevoditel' kaksemioticheskij objekt: k postanovke problem In Putevoditel' kaksemioticheskij object, $10-18$.

Kress, G. (2004). Reading Images: Multimodality, Representation and New Media. Retrieved from http://www.knowledgepresentation.org/BuildingTheFuture/Kress2/Kress2.html.

Prima V.V. (2015). English guide books as a genre of tourism discourse. In: Zapysty romano-germans'koi philologii. Odesa: KP OMD. 151-153.

Vinokur, G.O. (1939). O nekotoryh javlenijah slovoobrazovanija v russkoj tehnicheskoj terminologii. In Trudy Mosk. in-ta istorii, filosofiiiliteratury. Sbornikstatejpojazykovedeniju. (5), 3 - 54.

Travel to Ukraine. - [Jelektronnyjresurs]. - Rezhimdostupa: http://www.traveltoukraine.org

Ukraine // World travel guide. - [Jelektronnyjresurs]. - Rezhimdostupa: http://www.worldtravelguide.net/ukraine 